\title{
The Impact of Nitrogen and Phosphorus Dynamics on the Kinneret Phytoplankton: I: Cyanophytes-Peridinium Alternate
}

\author{
Moshe Gophen \\ Migal-Galilee Scientific Research Institute, Kiryat Shmone, Israel \\ Email: Gophen@Migal.org.il
}

How to cite this paper: Gophen, M. (2017) The Impact of Nitrogen and Phosphorus Dynamics on the Kinneret Phytoplankton: I: Cyanophytes-Peridinium Alternate. Open Journal of Modern Hydrology, 7, 257-273. https://doi.org/10.4236/ojmh.2017.74015

Received: July 30, 2017

Accepted: September 27, 2017

Published: September 30, 2017

Copyright $\odot 2017$ by author and Scientific Research Publishing Inc. This work is licensed under the Creative Commons Attribution International License (CC BY 4.0).

http://creativecommons.org/licenses/by/4.0/

\begin{abstract}
During 1970-2001, several ecological changes were documented in the Lake Kinneret Ecosystem: Decline of total Nitrogen (TN) and increase of total Phosphorus (TP) loads with a corresponding decline of TN/TP ratio. The phytoplankton assemblages indicated consequence Increase of Cyanobacteria accompanied by elevation of the biomass of Chlorophyta and Diatoms. The Kinneret ecosystem functioning represented two superimposed events: the decline of TN enhanced Cyanobacteria and elevation of TP that was reflected by an increase of Chloropytes and Diatoms. Removal of Nitrogen was achieved but P load remained high enough to enhance Chlorophyta and Diatoms. Consequently, a top priority of future management perspective should be reduction of Phosphorus inputs.
\end{abstract}

\section{Keywords}

Nitrogen, Phosphorus, Cyanobacteria, Peridinium, Kinneret

\section{Introduction}

The first record of bloom of the toxic-Nitrogen Fixer Cyanobacterium, Aphanizomenon ovalisporum occur during the summer of 1994 . This bloom event followed the disappearance of the annual regular Winter-Spring-early-Summer bloom forming dinoflagellate Peridinium gatunenze [1]. During the summer of 1987, I was on Sabbatical leave at the Biological Station, University of Oklahoma. A colleague gave me a lift to the D/FW International Airport to get on a flight to NZ SIL Congress. It gave me about a short time to tell him about my study. My message was short: nutrient loads in Lake Kinneret indicated a reduction of $\mathrm{Ni}$ trogen and a slight increase of Phosphorus resulting in the decline of N/P mass 
ratio. A prompt response directed me to a paper published in Science [2] where relations were presented between Cyanophyte blooms and the decline of N/P mass ratio. It was an induction for a long term research on Cyanophyte blooms in Lake Kinneret.

This short meeting and the paper became the first step of 7 years of scientific struggle aimed at emphasizing the awareness of N/P Ratio relation with Cyanobacteria blooms threatening Kinneret water quality [3]-[10], terminating in the summer of 1994 [3] [4]. In July-August 1994, the first record of $\mathrm{N}_{2}$-fixing cyanobacterium, Aphanizomenon ovalisporum bloom, was monitored in Lake Kinnerert. As quite often occurs in science, new idea, such as the low N/P ratio as the factor of $\mathrm{N}_{2}$ fixing cyanobacteria bloom in this case was not accepted by the Kinneret scientists. Several other options were suggested instead as promoters of those blooms, such as enhancement of Bosmina spp., long term of slow wind velocities conditions, high temperatures, enhancement of small size Bleak fishes population and high P availability [11]. One of the earlier (1984 Anonimus; [11]) documentations claimed: Unfortunately Lake Kinneret does not seem to fit well into the scheme of N/P ratio and Cyanobacteria enhancement and Kinneret Phytoplankton composition is a $\mathrm{Cu}^{2+}$ dependant. The following brief selection of citations were received shortly after the outbreak of $A$. ovalisporum supporting the N/P model opinions by foreign scientists (USA, Canada, UK) [11]: "I definitely share your view that water quality changes in Lake Kinneret may occur under the reduced N:P regime of recent years, assuming the current trends continue. Total $\mathrm{N}$ and $\mathrm{P}$ are well correlated with algal community structure because the algae responds to the supply ratio of $\mathrm{N}$ and P"; "Kinneret must be influenced by bottom-up events, including $\mathrm{N}$ and $\mathrm{P}$ ratios"; "Sorry about the Blue-Green bloom in Lake Kinneret but I would also have predicted it from the information you presented especially the falling TN:TP ratio"; The deteriorating conditions in Lake Kinneret are indeed discouraging. It is obviously a result of a number of interactions, but your predictions are right on"; "In fact I think low N:P ratios are excellent predictors for the development of Cyanobacteria generally"; "I could not agree more with your comments about the TN/TP ratio being at least part of the culprit"; "Congratulations on being right-sorry about Kinneret though. This will be one of the largest lakes to score dominant Aphanizomenon"; "Declining TN:TP loading selected for heterocystous blue-green. Sounds like Kinneret knows the script how to combat: reduce P input"; Significant step forward was implemented through a collaborative study which was documented by Gophen et al. [1]. This document summarized several years of research aimed at identifying causative factors for the first Lake Kinneret record of $\mathrm{N}_{2}$ fixing Cyanobacterium Aphanizomenon ovalisporum [1]. Nevertheless, it was indicated that the responses of other phytoplankton groups are also critical for a comprehensive outline of nutrient dynamics.

It was found that as a result of Nitrogen decline in Lake Kinneret simultaneously with the increase of Phosphorus loads not only Cyanophytes enhancement was recorded but also increase of Chlorophytes and Chrysophytes (Diatoms) bio- 
mass. The aim of the present study is to integrate the entire phytoplankton response to nutrient response with implications to ecosystem trait. The decline of $\mathrm{N} / \mathrm{P}$ ratio in Lake Kinneret enhanced not only $\mathrm{N}_{2}$-fixing Cyanobacteria-but also chlorophytes and Diatoms with significant implications on the Kinneret ecological features. Controversial indications were documented: Nutrient availabilities based model predicted long-term enhancement of cyanophyta but preliminary recent investigations has suspected Allelopathic relations between Peridinium and Microcystis as driven factor of phytoplankton biomass density in Lake Kinneret.

\section{Material and Methods}

Data including Phytoplankton biomass $\left(\mathrm{g}(\mathrm{ww}) / \mathrm{m}^{2}\right)$, Total Nitrogen, and Total Phosphorus (mg/l; ppm), calculated values of N/P mass ratio was taken from the LKDB-KLL (1969-2001) [12]. Two statistical methods were used: Linear Regression, and Fractional Polynomial (STATA 9.1). Monthly Mean values of Phytoplankton, TP and TN values were compiled as annual averages and statistical tests were carried out on Annual averages. Phytoplankton data is due to species groups of the Divisions of Cyanophyta, Chlorophyta and Chrysophyta (Diatoms). Phytoplankton data was documented in Station A and Chemical information is due to average values measured in samples collected in 7 stations throughout the entire lake (A, C, D, F, G, H, K) [13].

\section{Results}

Based on two types of regression relations several Dependent/Independent couples were evaluated: Fractional Polynomial (Figures 1-15) and linear regression (Table 1; Figures 16-18):

Algal Biomass Vs. TN, N/P ratio, and TP.

TP and TN Vs. Years (1969-2001).

The Significance Values $\left(\mathrm{p} \& \mathrm{r}^{2}\right)$ are given in Table 1:

Results in Table 1 represent the statistical parameters $\left(\mathrm{p}, \mathrm{r}^{2}\right)$ of the Regressions presented in the Figures as Fractional Polynomial. The temporal changes of TN, TP, N/P ratio and total biomass of Phytoplankton during 1969-2001 (Figures 1-3) are indicating increase of $\mathrm{TP}$, decline of $\mathrm{TN}$ and consequently decrease of $\mathrm{N} / \mathrm{P}$ mass ratio and increase of phytoplankton biomass. The related response of algal Biomass (Chlorophyta, Diatoms, Cyanophyta and obviously Total) to TP enhancement was prominent elevation (Figures 4-7). A decline of Total Phytoplankton in relation to TN deficiency is shown in Figure 8 Phytoplankton biomass (Chlorophyta, Cyanophyta, Diatoms and obviously Total) was clearly enhanced in relation to the low-level values of N/P ratios (Figures 9-12). Conclusive summary of the results indicates the decline of $\mathrm{TN}$, the enhancement of TP and obviously the decline of N/P ratios and Phytoplankton responsive enhancement. Peridinium response to increased loads of epilimnetic TN and TP (Figure 13, Figure 14) was enhancement. The decline of N/P ratio was 
Table 1. Probability (p) and Correlation Coefficient $\left(\mathrm{r}^{2}\right)$ values for Linear Regressions between given Dependent/Independent.

\begin{tabular}{ccc}
\hline Dependent/Independent & Probability $(\mathrm{p})$ & Correlation Coefficient $\left(\mathrm{r}^{2}\right)$ Trend \\
\hline Chlorophyta Vs TN & 0.012 & $0.187 \mathrm{D}$ \\
Total Phytoplankton Vs TN & 0.025 & $0.152 \mathrm{D}$ \\
Chlorophytra Vs N/P & 0.033 & $0.138 \mathrm{D}$ \\
Diatoms Vs N/P & 0.043 & $0.126 \mathrm{D}$ \\
Total Phyto Vs N/P & 0.066 & $0.105 \mathrm{D}$ \\
Cyanophyta Vs TP & 0.032 & $0.140 \mathrm{I}$ \\
Total Phyto Vs TP & 0.050 & $0.114 \mathrm{I}$ \\
TP Vs Year & 0.001 & $0.286 \mathrm{I}$ \\
TN Vs Year & 0.001 & $0.302 \mathrm{D}$ \\
Total Phyto Vs Year & 0.006 & $0.216 \mathrm{I}$ \\
Diatoms Vs Year & 0.002 & $0.264 \mathrm{I}$ \\
Chlorophyta Vs Year & 0.001 & $0.295 \mathrm{I}$ \\
Cyanophyta Vs Years & 0.006 & $0.222 \mathrm{I}$ \\
\hline
\end{tabular}

Trend: $\mathrm{D}=$ Decline; $\mathrm{I}=$ Increase .
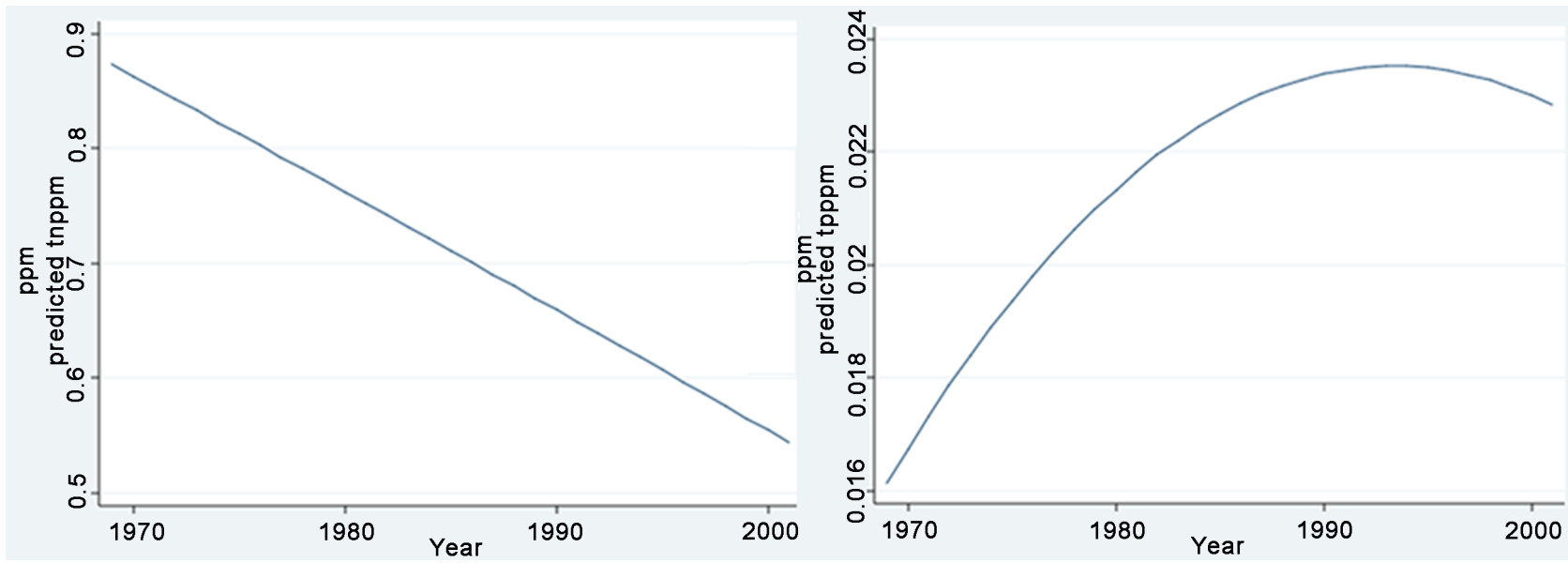

Figure 1. Fractional Polynomial Regression plot between Epilimnetic concentrations (ppm) of TN (left panel), TP (right panel) and years (1969-2001).

correlated with Peridinium decrease because lowered N/P was mostly resulted by TN decline. A graphical summary of the algal response to TN, TP and N/P fluctuations are given in Figures 16-18.

\section{Discussion}

Eukaryote algae were probably originated from Prokaryote cells of Cyanobacteria and/or Prochlorophyta due to $\mathrm{H}_{2} \mathrm{O}$ as Hydrogen donor similarity through the photosynthetic process. Nevertheless, photosynthetic pigments of the 


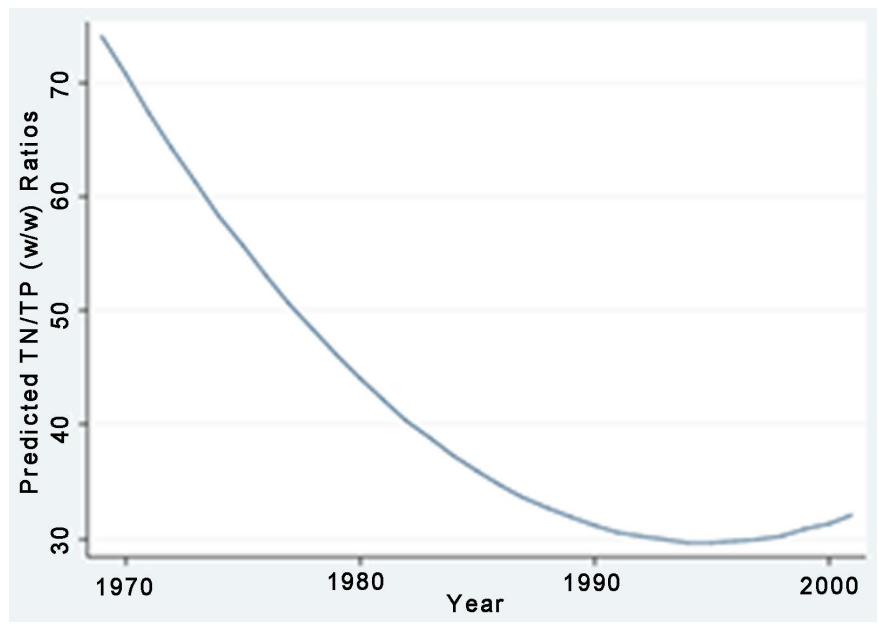

Figure 2. Fractional Polynomial Regression plot between Epilimnetic TN/TP (w/w) ratios and years (1969-2001).

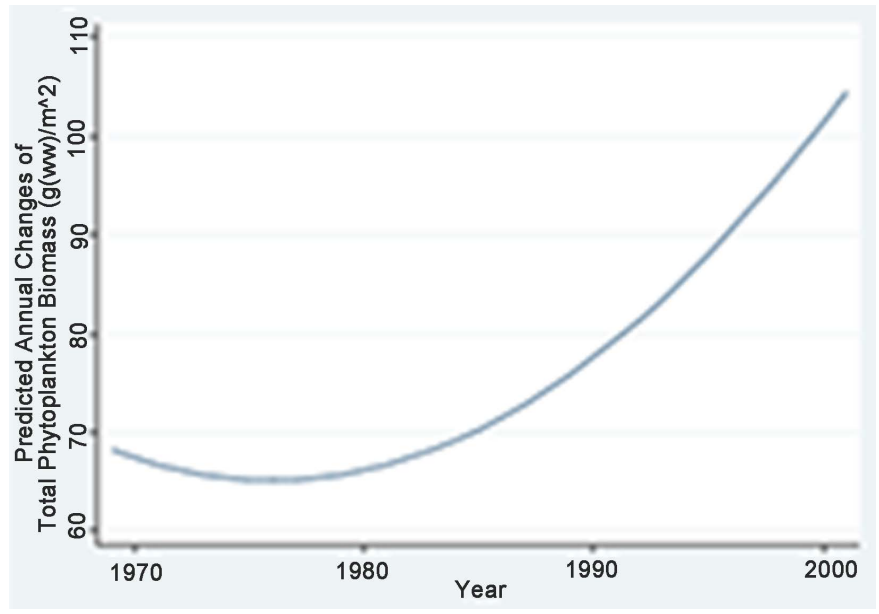

Figure 3. Fractional Polynomial Regression plot between Phytoplankton Biomass density $\left(\mathrm{g}(\mathrm{ww}) / \mathrm{m}^{2}\right)$ and years (1969-2001).

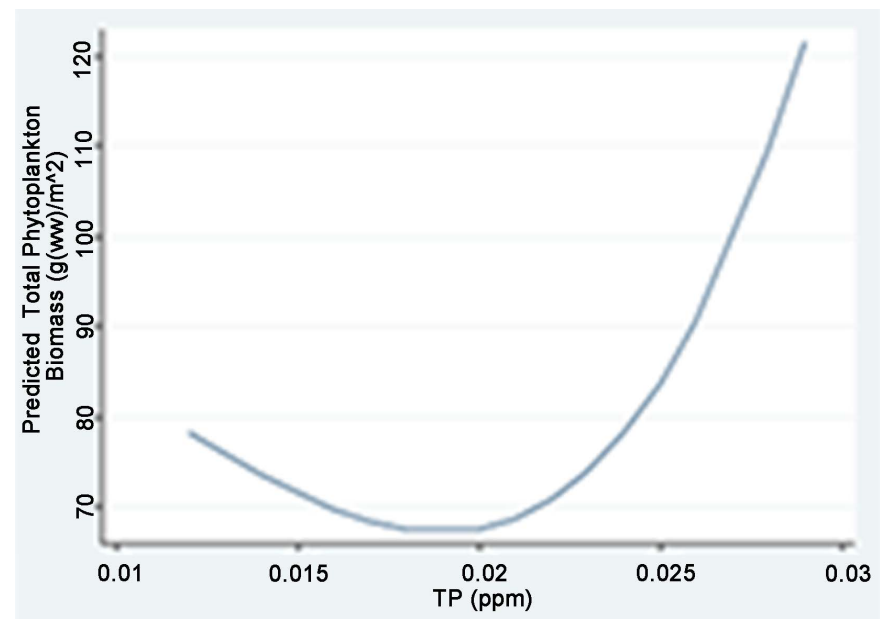

Figure 4. Fractional Polynomial Regression plot between Epilimnetic TP concentration (ppm) and Total Phytoplankton Biomass density $\left(\mathrm{g}(\mathrm{ww}) / \mathrm{m}^{2}\right)$. 


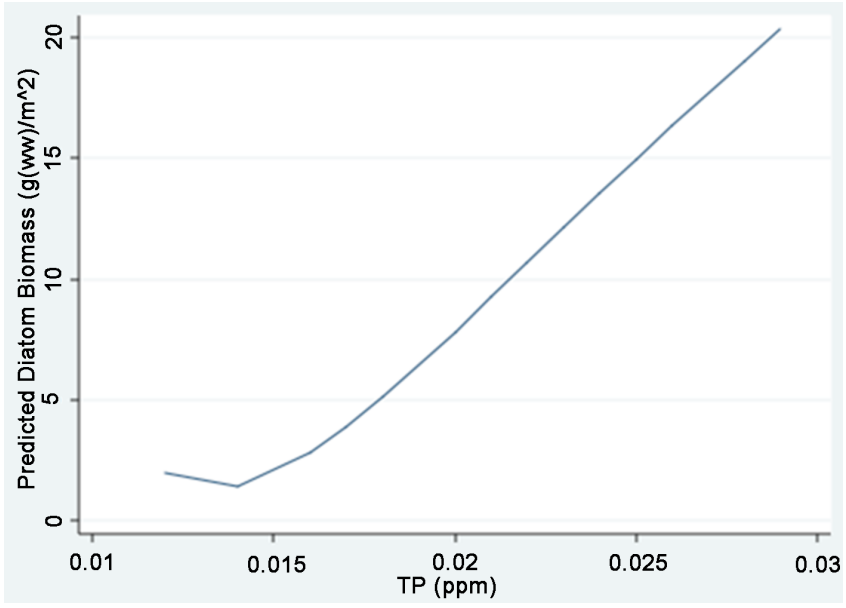

Figure 5. Fractional Polynomial Regression plot between Epilimnetic TP concentration (ppm) and Diatom Algal Biomass density $\left(\mathrm{g}(\mathrm{ww}) / \mathrm{m}^{2}\right)$.

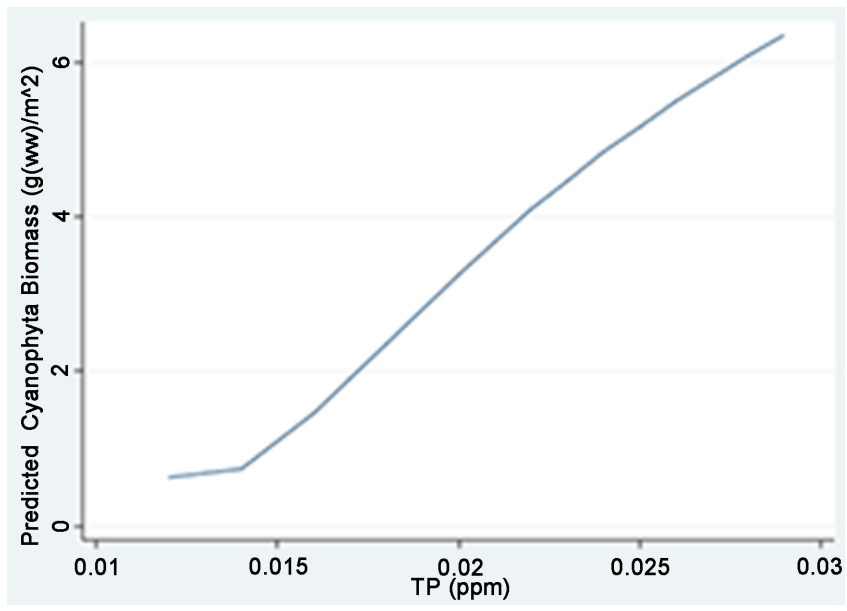

Figure 6. Fractional Polynomial Regression plot between TP concentration (ppm) and Cyanophyta algal density $\left(\mathrm{g}(\mathrm{ww}) / \mathrm{m}^{2}\right)$.

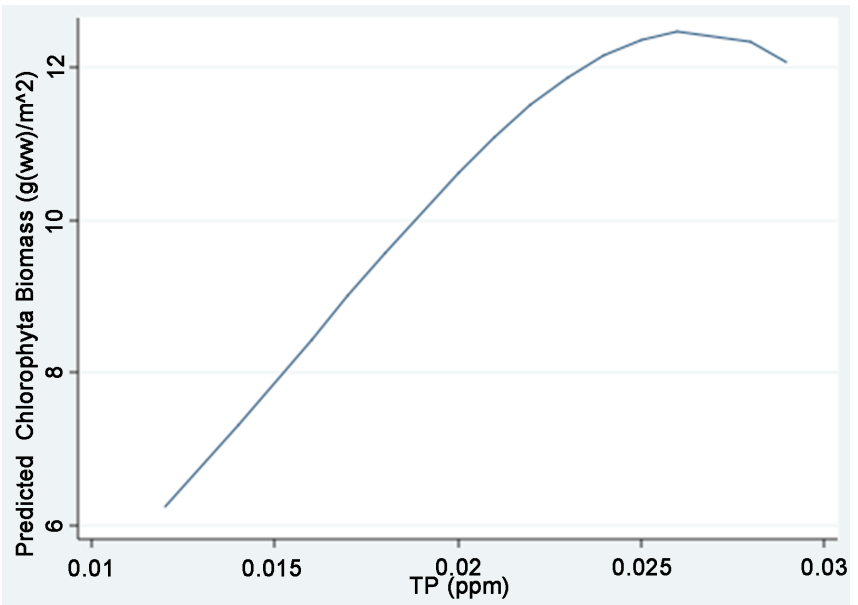

Figure 7. Fractional Polynomial Regression plot between Epilimnetic TP concentration (ppm) and Chlorophyta algal Biomass density $\left(\mathrm{g}(\mathrm{ww}) / \mathrm{m}^{2}\right)$. 


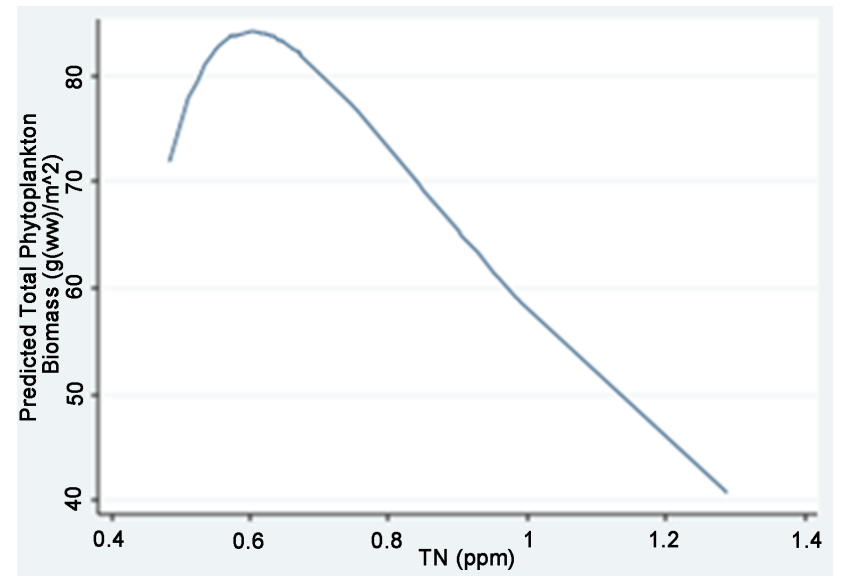

Figure 8. Fractional Polynomial Regression plot between Epilimnetic TN concentration (ppm) and Total Phytoplankton Biomass density $\left(\mathrm{g}(\mathrm{ww}) / \mathrm{m}^{2}\right)$.

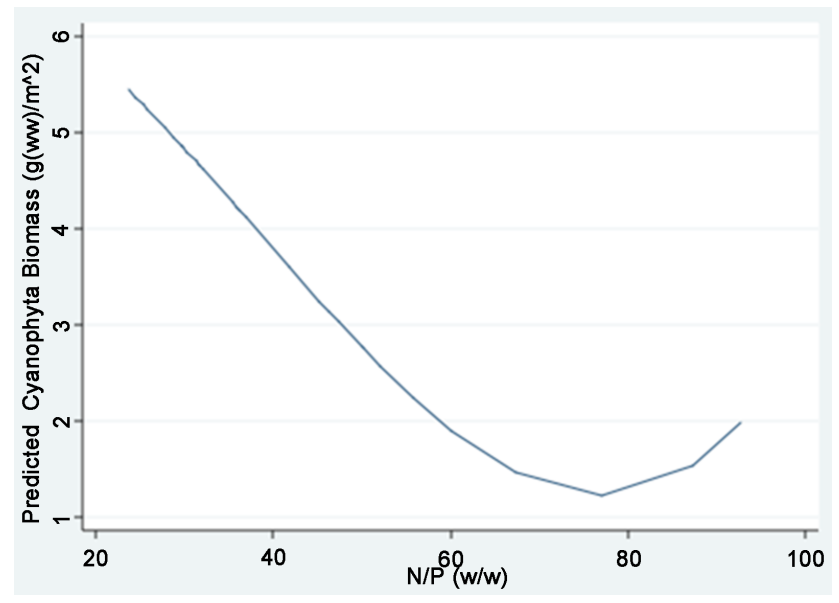

Figure 9. Fractional Polynomial Regression plot between Epilimnetic TN/TP (w/w) Ratios and Cyanophyta Algal Biomass density $\left(\mathrm{g}(\mathrm{ww}) / \mathrm{m}^{2}\right)$.

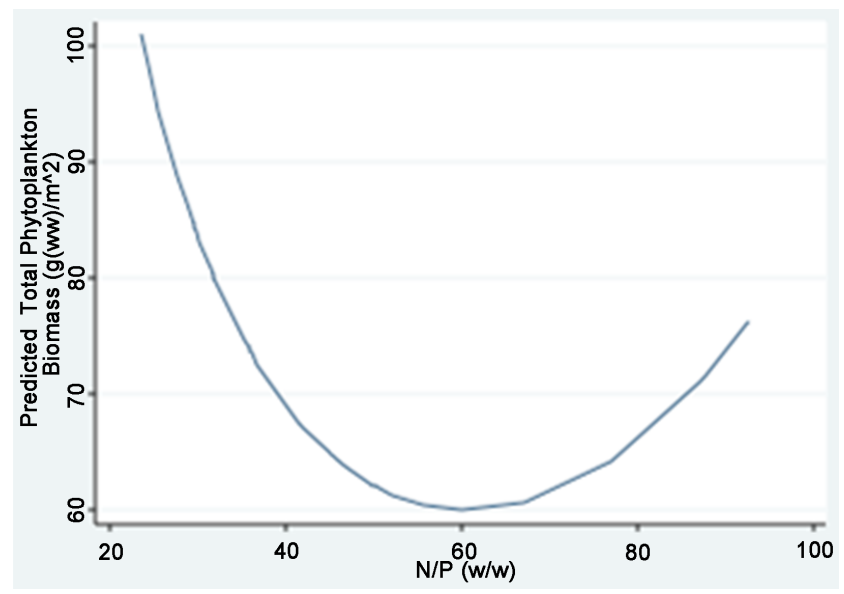

Figure 10. Fractional Polynomial Regression plot between Epilimnetic TN/TP (w/w) Ratios and Total Phytoplankton Biomass density $\left(g(w w) / m^{2}\right)$. 


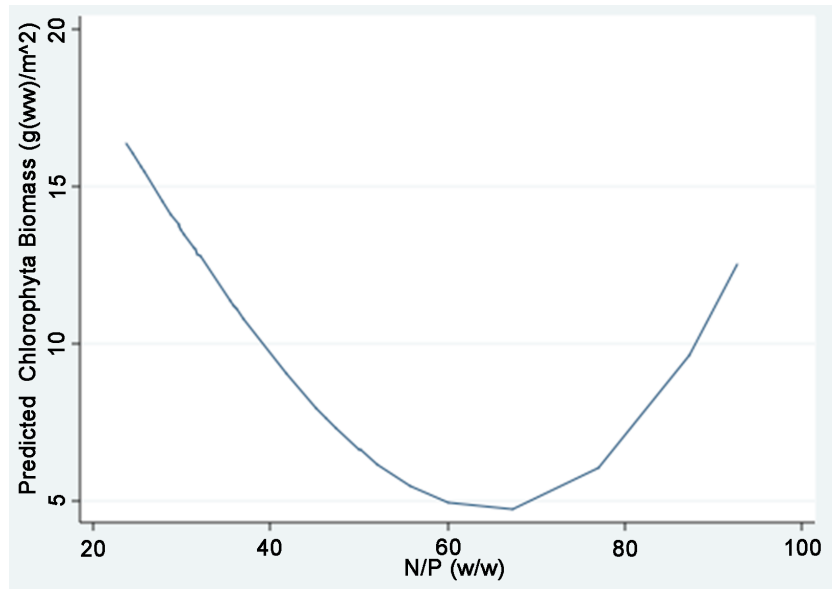

Figure 11. Fractional Polynomial Regression plot between Epilimnetic TN/TP (w/w) ratios and Chlorophyta algal Biomass density $\left(\mathrm{g}(\mathrm{ww}) / \mathrm{m}^{2}\right)$.

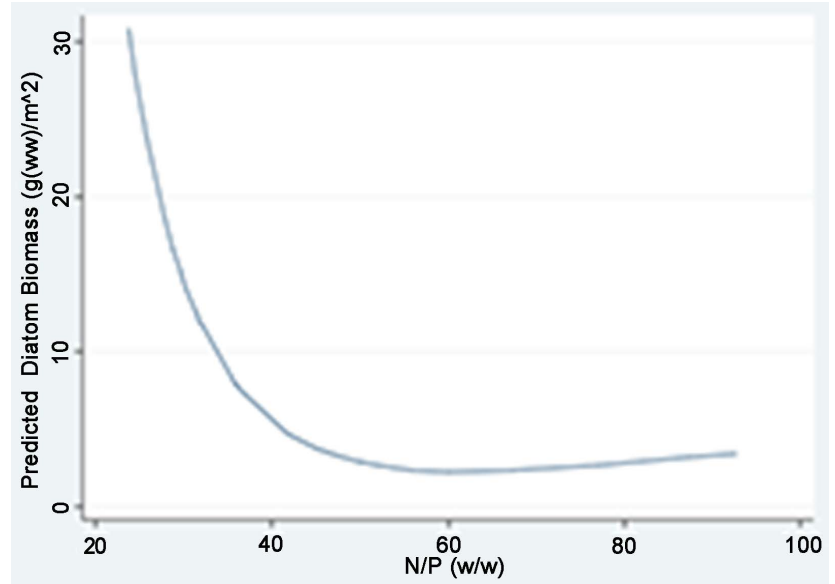

Figure 12. Fractional Polynomial Regression plot between Epilimnetic TN/TP (w/w) ratios and Diatoms algal Biomass density $\left(\mathrm{g}(\mathrm{ww}) / \mathrm{m}^{2}\right)$.

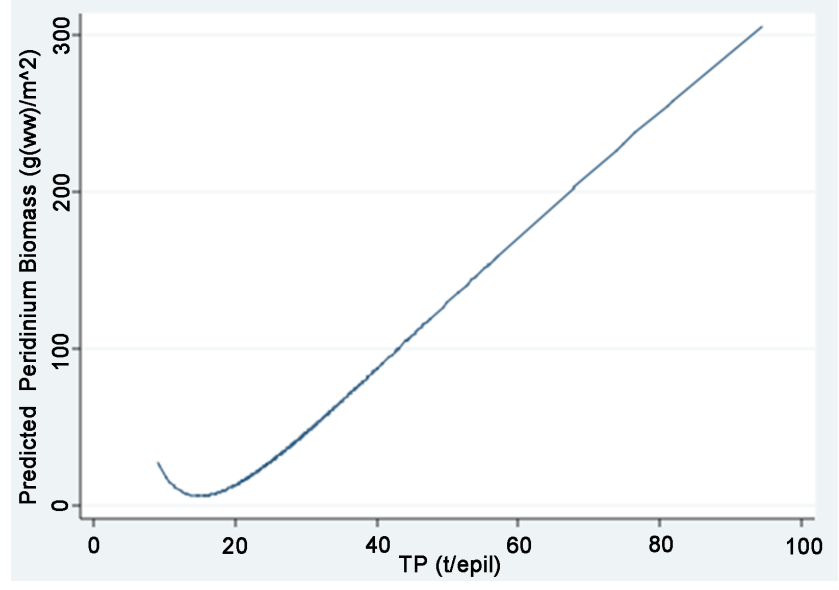

Figure 13. Fractional Polynomial Regression plot between Epilimnetic TP load (ton) and Peridinium Biomass density ( $(\mathrm{ww}) /$ $\mathrm{m}^{2}$ ). 


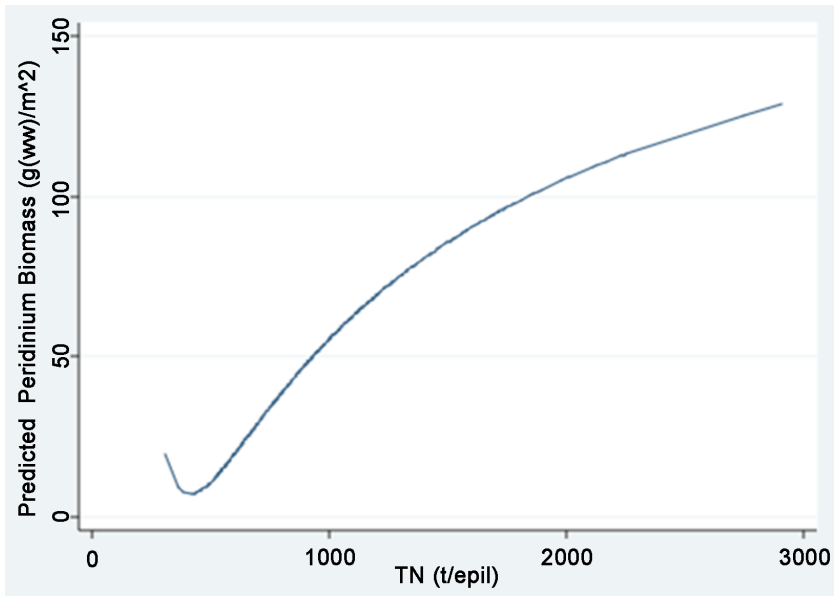

Figure 14. Fractional Polynomial Regression plot between Epilimnetic TN load (ton) and Peridinium Biomass density ( $(\mathrm{ww}) /$ $\left.\mathrm{m}^{2}\right)$.

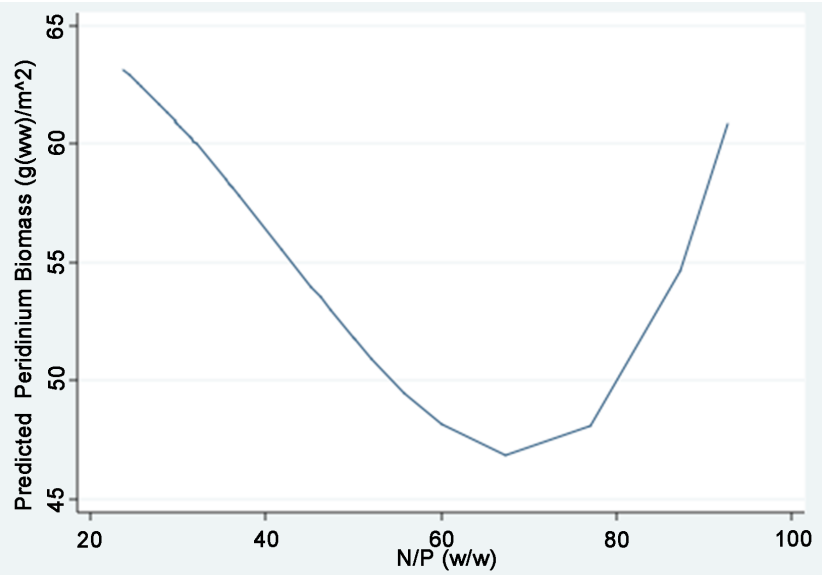

Figure 15. Fractional Polynomial Regression plot between Epilimnetic TN/TP (w/w) Ratios and Peridinium Biomass density $\left(\mathrm{g}(\mathrm{ww}) / \mathrm{m}^{2}\right)$.

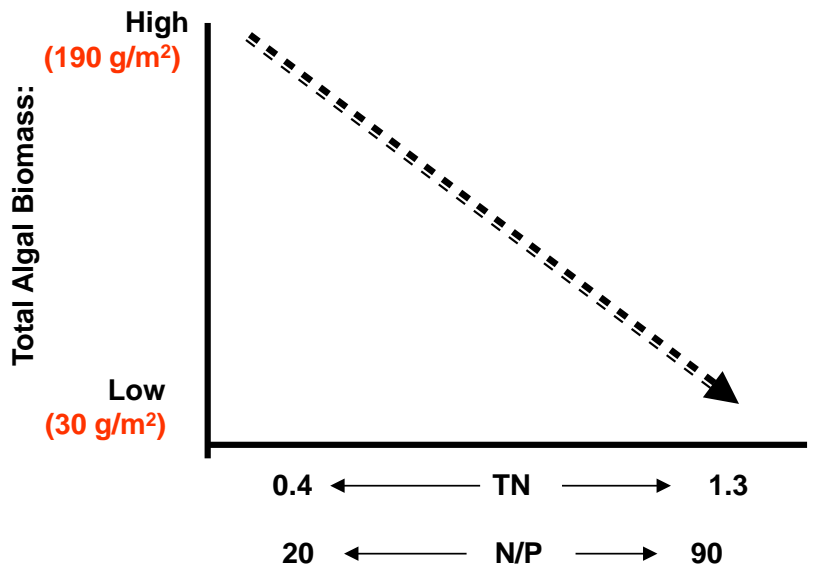

Figure 16. Schematic Chart Summary of the Trend of change of total phytoplankton biomass in relation to $\mathrm{TN}$ concentration (ppm) and TN/TP (w/w) Ratios. 


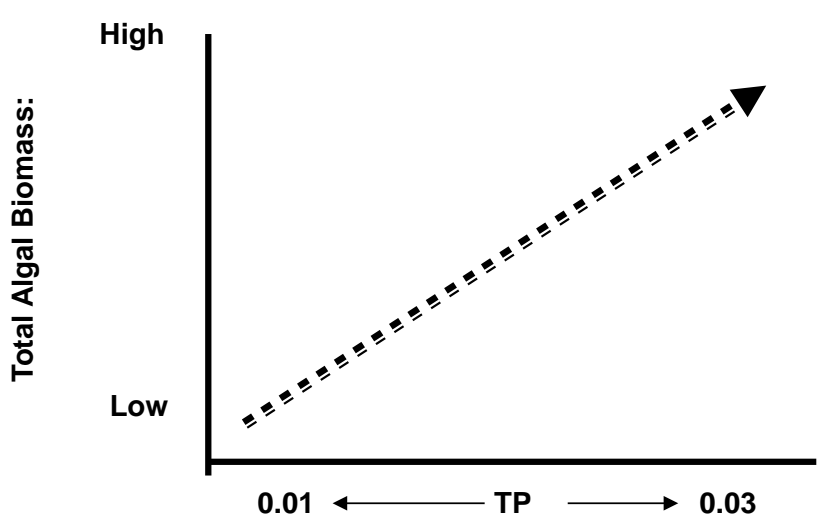

Figure 17. Schematic Chart Summary of the Trend of change of total Phytoplankton Biomass in relation to TN concentration.

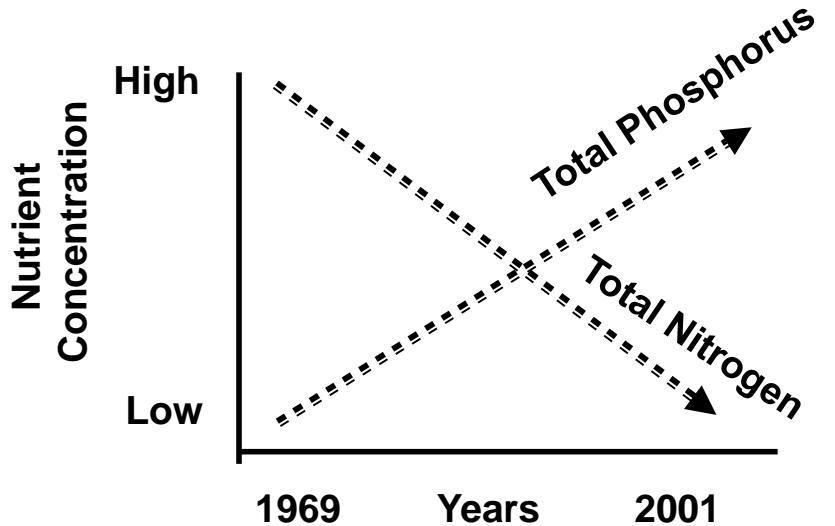

Figure 18. Schematic Chart Summary of the Temporal (Years: 1969-2001) Trend of changes of Total Nitrogen and Total Phosphorus.

Prochlorophyta are closer to those common among high terrestrial vascular plants and are, therefore, likely to be their origin in spite of several factors of similarity [14]. The role of TN in physiological processes of Cyanobacteria and Chlorophytes and Diatoms is rather similar but the Nitrogen source is dissimilar. On the contrary, TP sources for those algae are probably similar. Nitrogen fixation is a feature of some Cyanophyte species carrying heterocysts and bacteria. Some Cyanophyte species maintain fixation of atmospheric Nitrogen without visible heterocysts. The Cyanophyte distribution recently became a global issue as a result of consequence deterioration of water quality. Freshwater quality deterioration by Cyanophyta is due both to an unlimited source of atmospheric Nitrogen through Fixation capabilities and the toxicity of some species. Organic matter as a product of their high growth rate and the presence of toxins are common factors of freshwater deterioration. Falconer [15] documented 14 genera and 30 species of planktonic cyanobacterial species shown to contain toxins. Cook, Welch et al. [16] and Sas [17] documented the significant role of Phosphorus as a nutritional factor for Cyanophytes and its very strong influence on their growth rate and Cyanobacterial cells density if directly affected by $\mathrm{P}$ con- 
centration. They [16] [17] documented soluble P concentration below 10 - 20 $\mu \mathrm{g} / \mathrm{l}$ where this nutrient is a growth limitation in deep lakes. In Lake Kinneret, common ranges of $\mathrm{P}$ concentrations are TP- $10-30 \mu \mathrm{g} / \mathrm{l}$, Soluble $\mathrm{P}-1-4 \mu \mathrm{g} / \mathrm{l}$ and P-PO 4 - $2 \mu \mathrm{g} / \mathrm{l}$. Mur, Skulberg et al. [18] indicated the higher affinity of Cyanobacteria for $\mathrm{P}$ than Chlorophytes under conditions of $\mathrm{P}$ limitation as exist in Lake Kinneret. Oliver and Ganf [19] studied the relationship between nutrient availability, algal growth and their relative abundance. Although drinking water quality deterioration by chlorophytes and chrysophytes has no relation to toxicity, their biomass density is likely to be quite a common threat in water supply systems. The major concerns are their photosynthetic Carbon fixation with consequent organic matter concentration. Therefore, the analysis of $\mathrm{N}$ and $\mathrm{P}$ impact on water quality include, besides Cyanophyta, Chlorophyta and Chrysophyta. With regard to soluble forms of $\mathrm{N}$ and $\mathrm{P}$, the higher the ratio is towards $\mathrm{N}$, diatoms and chlorophytes are dominant, and when $\mathrm{N}$ relatively diminishing, cyanophytes take over. It was suggested that $\mathrm{P}$ storage in Cyanobacteria may be larger than in chlorophytes and Diatoms providing them with competitive advantage [20]. Tandeau and Houmard [21] indicated that under conditions of inorganic Nitrogen depletion $\mathrm{N}_{2}$-fixers Cyanophytes have a substantial ecological advantage. $\mathrm{P}$ load reduction might be reflected in reduced Cyanobacteria only under conditions of $\mathrm{P}$ limitation and $\mathrm{N}_{2}$-fixer cyanobacteria might have a competitive advantage under $\mathrm{N}$ limitation [15]. Therefore, Cyanophyte suppression will be efficient by $\mathrm{P}$ removal. Nevertheless, the response to $\mathrm{P}$ removal might be a very slow process in Lake Kinneret due to the long retention time of nutrients and the moving of $\mathrm{P}$ between chlorophytes, Diatoms and Cyanophytes [22]. Nutrient ratios $(\mathrm{N}: \mathrm{P})$ are not always reliable indicators because the critical limiting level of total inorganic nitrogen required for the induction of $\mathrm{N}_{2}$ fixation must be reached regardless of the $\mathrm{N}: \mathrm{P}$ ratio [19] [23].

The ecological impact of $\mathrm{N}$ decline and $\mathrm{P}$ increase and the shift from $\mathrm{N}$ to $\mathrm{P}$ limitation within the Kinneret ecosystem was previously documented [3] [5] [6] [7] [24] [25] [26] [27] [28]. Although the implication of those nutrient changes of availability was considered [8] [10] [29], the precise impact on the entire Phytoplankton community was not sufficiently included. In their [1] study about the Kinneret invasion by $\mathrm{N}_{2}$-Fixing Cyanobacterium A. ovalisporum, the ecological structure that enabled the invasion during the summer of 1994 was formulated as NDPS, i.e. Nitrogen Deficiency Phosphorus Sufficiency. The present study analyzed a 32-year period aimed at exploring the impact of TN and TP composition on the Phytoplankton community structure. Of course, the study of the issue of the impact of nutrient on Phytoplankton community structure requires a wider spectrum of parameters as well as spatial and temporal ranges to be comprehensively evaluated. The present study is a minor deepening of the temporal evaluation of the $\mathrm{P}$ and $\mathrm{N}$ collaborative influence on the Kinneret phytoplankton compartments of Chlorophyta, Diatoms and Cyanophyta. Undoubtedly during the test period (1969-2001), there was a decline of $\mathrm{N}$ and an increase of $\mathrm{P}$ as presented in Gophen et al. (1999). Although such conditions fa- 
vored the flourishing of Cyanobacteria, Diatoms and Chlorophyte were enhanced as well. Why is this curious? This curiosity was not responded to in earlier studies where the focus was on $\mathrm{N}: \mathrm{P}$ ratio decline, the ecosystem shift from $\mathrm{P}$ to $\mathrm{N}$ limitation and $\mathrm{N}_{2}$-Fixiers Cyanobacterium trait. In order to answer those questions, the temporal capacity changes of total phytoplankton, Chlorophyta, Cyanophyta and Diatoms in relation to fluctuations of $\mathrm{N}$ and $\mathrm{P}$ in the Kinneret were analyzed. The long term analysis indicated $\mathrm{N}$ decline, $\mathrm{P}$ increase, and obviously $\mathrm{N}: \mathrm{P}$ ratio decline, accompanied by Phytoplankton biomass enhancement (Drawing Figures 15-17). In previous studies, the focus was given only to the $\mathrm{N}: \mathrm{P}$ ration decline which induced Cyanophyta enhancement. It is likely that in spite of developed conditions of $\mathrm{N}$ limitation, the slight increase of $\mathrm{P}$ induced the increase of the biomass of Chlorophytes and Diatoms densities. This condition is a crucial development for the Kinneret ecosystem due to its ecosystem services, which include drinking and irrigation water supply, fishery resources and intensive aquatic recreational activity. The density of Chlorophyta and Diatoms is a Key factor for the qualification of water quality, especially in the summer period.

The importance and indirect effects of TN, TP, and phytoplankton relations to other factors in the Kinneret food web are exemplified in the case study of unwanted fish removal. The ecological parameter of Zooplankton density and its algal grazing rate capacity and, therefore, impact on water quality might have a significant influence on the biomass of Chlorophytes and Diatoms. Therefore, zooplankton grazing capacity is critical for the prevention of organic matter enhancement. During late 1980's and early 1990's, the Kinneret Zooplankton capacity was reduced as a result of Biomass decline due to predaceous Bleak fishes enhancement. A recommended policy was implemented to subsidize the removal of unwanted Bleaks but its impact was partly unpredicted, the zooplankton biomass enhanced but Chlorophyta and Diatoms biomass was increased simultaneously. It is a reconfirmation of Bendorffs' ecological rule [30] [31]: "Biomanipulation (removal of unwanted fish) might give successful result in deep lakes if $\mathrm{P}$ is under control and can be reduced." Benndorf [30] [31] indicated 5 key factors influencing the management success of Top-Down Biomanipulation (removal of unwanted zooplanktivore fishes) Control of Phytoplankton: Short time scale, deep lake, sufficient reduction of external and internal sources of available Phosphorus for Phytoplankton, and high mixing depth causing significant light limitation for the photosynthetic activity of the phytoplankton.

Increasing zooplankton predation capacity unexpectedly was not accompanied by phytoplankton decline. Because of the enhancement of $\mathrm{P}$ availability, there was algal biomass proliferation. Conclusively, the NDPS rule [1] should be upgraded as "The NDPS improved Cyanophyta growth rate and P increase upgraded conditions for Chlorophyta and Diatoms growth". The Kinneret ecosystem presented the following: Decline of $\mathrm{N}$ and obviously N:P enhanced Cyanophyta but the increase of $\mathrm{P}$ caused elevation of Chlorophyta and Diatoms. In other words, Cyanophyta increases if $\mathrm{N}$ is limited and Chlorophytra and $\mathrm{Di}$ - 
atoms are $\mathrm{P}$ limited and not severely affected by the $\mathrm{N}$ limitation.

The long Historical Ecology of the Lake Kinneret Ecosystem is telling us that, during the 1970's and 1980's, nutrient conditions (N, P, N/P) were more or less stable and, therefore, phytoplankton biomass fluctuations were unpredicted. During the late 1980's $\mathrm{N}$ loads started declining as a result of the significant removal of external inputs but $\mathrm{P}$ did not change because its internal sources together with air-borne deposition are dominant. At the end of the 1980's the N deficiency was recognized as a prediction of $\mathrm{N}_{2}$-fixing Cyanophyte threat which became realistic in 1994 .

\section{Allelopathy Vs. Nutrient Dynamics}

Allelopathy, usually defined as chemically elicited interactions between plants, is mediated by many types of compounds. Allelopathic compounds could interact by inhibition of synthesis accumulation or utilization of energy rich compounds, or have specific effect in other organisms [32]. The Allelopathic relations between Peridinium and Microcystis is suggested.

Until early 1990's Pridinium produced the highest biomass among phytoplankters in Lake Kinneret. From early 1990's Peridinium was replaced by Cyanophytes with Microcystis dominance. The study presented in this paper indicates nutrient dynamics as the major impact causing that change. Nevertheless, it is not impossible that the factor of antagonistic Allelopathy is involved as well [12]. Although such a case of Cyanophtes enhancement replacing other algal groups is common in nature long term analysis is critical for the investigation of alter causation factors. Irregular outbreaks of Microcystis were commonly recorded periodically in Lake Kinneret from 1970 and onwards. Long term outbreaks of Microcystis in Lake Kinneret were documented from early 2000's whilst the beginning of Peridinium decline already started earlier from late 1980's when it was partly replaced by Cyanophytes other than Microcystis. Serruya and Pollingher [33], suggested that early winter floods contributed to the lake a bulk of nitrifying bacteria included in the Hula Valley Peat soil drainage. Consequent nitrification in the lake increased production of Nitrates. The periodical increased availability of Nitrates and the absence of potential competitor, Peridinium, were therefore accompanied by short-term heavy blooms of Microcystis. Later on in late winter Peridinium blooms were usually developed. This case exemplify an event of two not overlapped periodical bloom forming by $\mathrm{Pe}$ ridinium and Microcystis both utilize mutual nutrient (Nitrate) when available. This pattern of phytoplankton succession in Lake Kinneret was an annual routine not overlapped sequence, rarely the two species included and always with Peridinium until early 1990's. The decline of Peridinium and the cyanophytes enhancement were not chronologically overlapped events. Nevertheless, it is possible that shortly after Cyanophyta became the dominant two factors, Allelopathy and nutrient dynamics simultaneously suppressed Peridinium bloom. The present study confirm Nitrogen deficiency which enhanced Cyanobacteria. Moreover, Nitrogen is a known limiting nutritional factor for Peridinium bloom 
formation [34]. Moreover, Phosphorus supply is favored by Cyanophyta, Chlorophyta and Diatoms and much less by Peridiinum. The reason for that is indicated in the life cycle of Peridinium. During late spring-early summer the heavy bloom of Peridinium crushed abruptly. Then, a diapause stage start by modification of vegetative cells into cysts which are settled down to the bottom sediments. During Summer-Fall and early Winter those cysts incorporate Phosphorus from the sediments being preserved as an intra-cell stock of P. In late winter the cysts germinate and vegetative form emerge from the cysts as free swimming form maintaining a high rate of cell division and the bloom is created [35]. This heavy bloom is a significant stock of Phosphorus which is released mainly into the epilimnion during bloom crush and cells disintegration. The enhanced bioavailable $\mathrm{P}$ enhance non-Peridinium phytoplankters, as recorded in August-September 1994 when Aphanizomenon ovalisporum first bloom recorded in Lake Kinneret [1]. Phosphorus input into the Kinneret Ecosystem is mostly due to internal sources and atmospheric dust deposition. Those sources are not under anthropogenic control and therefore create a controversial situation: Peridinium is better than toxic cyanophyte dominance. In order to achieve it, enhancement of Nitrogen and reduction of Phosphorus inputs are recommended. Reduction of $\mathrm{P}$ is complicated due to un-limited bottom sources and un-controlled atmospheric deposition. Therefore, under present conditions of dominant toxic Cyanophyta which is driven by Nitrogen deficiency the return of Peridinium is prevented both by lack of Nitrogen and Allelopathic factors produced by the Blue-greens. Furthermore, the Peridinium return might cause enrichment of the epilimnion with bio-available Phosphorus [33] which is a beneficiary to toxic Cyanophyta. Early studies confirm the present suggestion that Phosphorus reduction and $\mathrm{Ni}$ trogen enhancement might be beneficial to reduction of toxic Blue-greens. Several years during the post-Peridinium arena blooms of this algae reappeared probably as a result of heavy Nitrogen inputs conveyed by floods. It is probably an indication that absence of Peridinium bloom is due more to Nitrogen limitation and less to Allelopathic influence. The reduction of Peridinium cysts mediated bio-available Phosphorus flux from the sediments is recommended. It can be achieved if the Peridinium blooms will not reappear. The anthropogenic operations aimed at declining Phosphorus contribution from the drainage basin sources are compatible. Nitrogen limited, Phsphorus deficiency and not heavy Cyanophytes blooms followed by thorough awareness and routine monitoring of toxicity is therefore recommended structure of the Kinneret ecosystem.

\section{Conclusive Summary}

During 1970-2001, several ecological changes occurred in the Lake Kinneret Ecosystem. Among others, there were a decline of Nitrogen and an increase of Phosphorus loads with a corresponding decline of TN/TP ratio. Consequently, the community structure of the phytoplankton indicated respective modifications [36]: Increase of Cyanobacteria which is attributed to their advantage of atmospheric $\mathrm{N}_{2}$-fixing ability. The elevation of Chlorophyta and Chrysophyta (Di- 
atoms) biomasses is attributed to the increase of $\mathrm{P}$ availability without the interference of TN deficiency (Figures 15-17). The ecosystem functioning represented two superimposed events: the decline of TN enhanced Cyanobacteria and the elevation of TP that was reflected by an increase of Chlorophytes and Diatoms biomass. The previously formulated ecosystem structure as NDPS [1] is expanded to include also nano-phytoplankton enhancement. The dominant impact on phytoplankton density and composition is due to Nutrient availabilities whilst other ecological parameters are probably classified as secondary factors in the Lake Kinneret Ecosystem. Removal of $\mathrm{N}$ from the Lake Kinneret inputs was achieved but $\mathrm{P}$ load is high. Therefore, a top priority of the future perspective of lake management is $\mathrm{P}$ reduction.

\section{References}

[1] Gophen, M., Smith, V.H., Nishri, A. and Threlkeld, S.T. (1999) Nitrogen Deficiency, Phosphorus Sufficiency, and the Invasion of Lake Kinneret, Israel, by $\mathrm{N}_{2}$-Fixing Cyanobacterium Aphanizomenon Ovalisporum. Aquatic Sciences, 1, 1-14. https://doi.org/10.1007/PL00001326

[2] Smith, V.H. (1983) Low Nitrogen to Phosphorus Ratios Favor Dominance by Blue-Green Algae in Lake Phytoplankton. Science, New Series, 221, 669-671. https://doi.org/10.1126/science.221.4611.669

[3] Gophen, M. (1987) Bottom-Up, Top-Down Forces in Lake Kinneret and Ecosystem Management (Abstract). Annual Meeting, American Society of Limnology and Oceanography (ASLO), Madison, 14-18 June 1987, 16.

[4] Gophen, M. and Serruya, S. (1987) Lake Kinneret Management Aimed at Water Quality Protection (Abstract). Annual Meeting of the Israeli Society for Ecology and Environmental Quality Sciences, Ohalo, 24-25 May 1987, 30 (in Hebrew).

[5] Gophen, M. and Serruya, S. (1990) Fish Predation Effects on Plankton Community Structure in Large Lakes: Lake Kinneret. In: Tilzer, M. and Serruya, C., Eds., Ecological Structure and Function in Large Lakes, Springer-Verlag, Berlin, 645-660. https://doi.org/10.1007/978-3-642-84077-7 35

[6] Gophen, M., Serruya, S. and Threlkeld, S.T. (1990) Long Term Patterns in Nutrients, Phytoplankton and Zooplankton of Lake Kinneret and Future Predictions for Ecosystem Structure. Archiv für Hydrobiologie, 118, 449-460.

[7] Gophen, M. (1992) Long-Term Changes of Plankton-Communities in Lake Kinneret, Israel. Asian Fisheries Science, 5, 291-302.

[8] Gophen, M. (1994) Eutrophication in Lake Kinneret: Yes or No? The Biosphere, Environmental Ministry Magazine, 23, 23-27 (in Hebrew).

[9] Gophen, M. (1994) Blue Green Algae in Lake Kinneret. ASLO Bulletin, 6, 9.

[10] Gophen, M. (1999) Prediction of an $\mathrm{N}_{2}$-Fixing Cyanobacteria Bloom in Lake Kinneret (Israel) Based on N and P Balance. Verhandlungen des Internationalen Verein Limnologie, 27, 1239-1242.

[11] Gophen, M. (1970-2001) Kinneret Achives, a Private Open Collection; Availability upon Request.

[12] LKDB-KLL (1969-2001) Kinneret Limnological Laboratory, IOLR, Annual Reports. (In Hebrew)

[13] Serruya (1978) Chapter: Water Chemistry. In: Serruya, C., Ed., Lake Kinneret Mo- 
nograpiae Biologicae, Junk Publishers, 185-205.

[14] Serruya, C. and Berman, T. (1975) Phosphorus, Nitrogen and the Growth of Algae in Lake Kinneret. Journal of Phycology, 11, 155-162. https://doi.org/10.1111/j.1529-8817.1975.tb02764.x

[15] Zamski, E. (2017) Chapter: Plants Origin. In: Magnes, Y.L., Ed., Processes and Mechanisms in $G$ the Plant World, Books Publisher, the Hebrew University, Jerusalem, 9-12. (In Hebrew)

[16] Falconer, I.R. (2005) Cyanobacterial Toxins of Drinking Water Supplies, Cylindrospermopsins and Microcystins. CRS Press, Boca Raton, London, New York, Washington DC.

[17] Cook, G.D., Welch, E.B., et al. (1993) Restoration and Management of Lakes and Reservoirs. Lewis Publisher, Boca Raton.

[18] Sas, H. (1989) Lake Restoration by Reduction of Nutrient Loading: Expectations, Experiences Extrapolations. Acdemia Verlag Richarz, St. Augustin.

[19] Mur, L.R., Skulberg, O.M., et al. (1999) Cyanobacteria in the Environment. In: Chorus, I. and Bartram, J., Eds., Toxic Cyanobacteria in Water. A Guide to Rheir Public Health Consequences, Monitoring and Management, London, E. and FN Spon (on Behalf of WHO), 15-40.

[20] Oliver and Ganf (2000) Chapter: Freshwater Blooms. In: Whitton, B.A. and Potts, M., Eds., Eds., The Ecology of Cyanobacteria, Their Diversity in Time and Space, Kluwer Academic Publishers, Dordrecht, 150-194.

[21] Sommer, U. (1985) Comparison between Steady State and Non-Steady State Competition: Experiments with Natural Phytoplankton. Limnology and Oceanography, 30, 335-346. https://doi.org/10.4319/lo.1985.30.2.0335

[22] Tandeau de Marsac, N. and Houmard, J. (1993) Adaptation of Cyanobacteria to Environmetal Stimuli: New Steps towards Molecular Mechanism. FEMS Microbiology Reviews, 104, 119-190. https://doi.org/10.1111/j.1574-6968.1993.tb05866.x

[23] Chorus, I. and Mur, L. (1999) Preventative Measures. In: Chorus, I. and Bartam, J., Eds., Toxic Cyanobacteria in Water. A Guide to Their Public Health Consequences, Monitoring and Management, London, E and FN Spon (on Behalf of WHO), 236-273.

[24] Horrn, A.J. and Cummins, M.L. (1989) Phytoplanktonic Monotony: Low Spatialheterogeneity for Nitrogen Fixation, Algae, Nutrients, and Temperature but not for Zooplankton, in Loake Rotongaio New Zealand. Archiv für Hydrobiologie-BeiheftErgebnisse der Limnologie, 32, 83-97.

[25] Gophen, M. (2011) The Cladoceran Trophic Status in the Nitrogen Limited Ecosystem of Lake Kinneret (Israel). Journal of Environmental Biology, 32, 455-462.

[26] Gophen, M. (2015) The Impact of Available Nitrogen Defficiency on Long-Term Changes in the Lake Kinneret Ecosystem. Open Journal of Ecology, 5, 147-157.

[27] Gophen, M. (2015) Experimental Study of the Aphanizomenon ovalisporum Response to Nitrogen Fertilization in the Sub-Tropical Eu-Meso-Trophic Lake Kinneret (Israel). Open Journal of Ecology, 5, 259-265.

https://doi.org/10.4236/oje.2015.56020

[28] Gophen, M. (2016) Innovated Design of Lake Kinneret (Israel) and Its Drainage Basin. Research in Business and Management, 3, 1-15.

[29] Gophen, M. (2016) Limnological Changes in the Lake Kinneret (Israel) Ecosystem: The Beginning and Its Significance. Open Journal Of Hydrology, 6, 140-150. https://doi.org/10.4236/ojmh.2016.63012 
[30] Gophen, M. (1994) Eutrophication in Lake Kinneret: Yes or No? The Biosphere, Environmental Ministry Magazine, 23, 23-27.

[31] Benndorf, J., Kneschke, H., Kossatz, K. and Penz, E. (1984) Manipulation of the Pelagic Food Web by Stocking with Predacious Fishes. International Review of Hydrobiology, 69, 407-428. https://doi.org/10.1002/iroh.19840690308

[32] Benndorf, J., Boing, W., Koop, J. and Neubauer, I. (2002) Top-Down Control of Phytoplankton: The Role of Time Scale, Lake Depth and Trophic State. Freshwateriology, 47, 2282-2295.

[33] Seigler, D.S. (2006) Basic Pathwaysfor the Origin of Allelopathic Compounds. In: Reigosa, M.J., Pedrl, N. and Gonzalez, L., Eds., Allelopathy: A Physiological Process with Ecological Implications, Springer, Berlin, 1-61.

[34] Serruya, C. and Pollingher, U. (1971) An Attempt at Forecasting the Peridinium Bloom in Lake Kinneret (Lake Tiberias). Verhandlungen des Internationalen Verein Limnologie, 19, 277-291.

[35] Pollingher, U. and Serruya, C. (1978) Chapter: Peridinium: Growth Pattern in the Lake. In: Lake Kinneret Monographiae Biologicae, Vol. 32, Junk Publishers, 285-291.

[36] Zohary, T. (2004) Changes of the Phytoplankton Assemblage of Lake Kinneret after Decades of a Predictable Repetitive Pattern. Freshwater Biology, 49, 1355-1371. https://doi.org/10.1111/j.1365-2427.2004.01271.x 